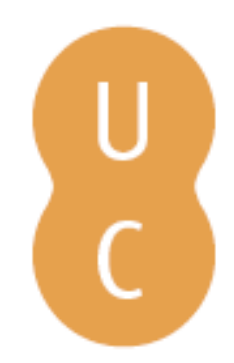

\title{
pommalina
}

\section{Growth and maturity profile of youth swimmers in Mexico}

Autor(es): $\quad$ Peña Reyes, Maria E.; Malina, Robert M.

Publicado por: Imprensa da Universidade de Coimbra

URL

persistente: URI:http://hdl.handle.net/10316.2/38852

DOI: $\quad$ DOI:http://dx.doi.org/10.14195/978-989-26-1169-3_5

Accessed : $\quad$ 26-Apr-2023 12:40:49

A navegação consulta e descarregamento dos títulos inseridos nas Bibliotecas Digitais UC Digitalis, UC Pombalina e UC Impactum, pressupõem a aceitação plena e sem reservas dos Termos e Condições de Uso destas Bibliotecas Digitais, disponíveis em https://digitalis.uc.pt/pt-pt/termos.

Conforme exposto nos referidos Termos e Condições de Uso, o descarregamento de títulos de acesso restrito requer uma licença válida de autorização devendo o utilizador aceder ao(s) documento(s) a partir de um endereço de IP da instituição detentora da supramencionada licença.

Ao utilizador é apenas permitido o descarregamento para uso pessoal, pelo que o emprego do(s) título(s) descarregado(s) para outro fim, designadamente comercial, carece de autorização do respetivo autor ou editor da obra.

Na medida em que todas as obras da UC Digitalis se encontram protegidas pelo Código do Direito de Autor e Direitos Conexos e demais legislação aplicável, toda a cópia, parcial ou total, deste documento, nos casos em que é legalmente admitida, deverá conter ou fazer-se acompanhar por este aviso. 


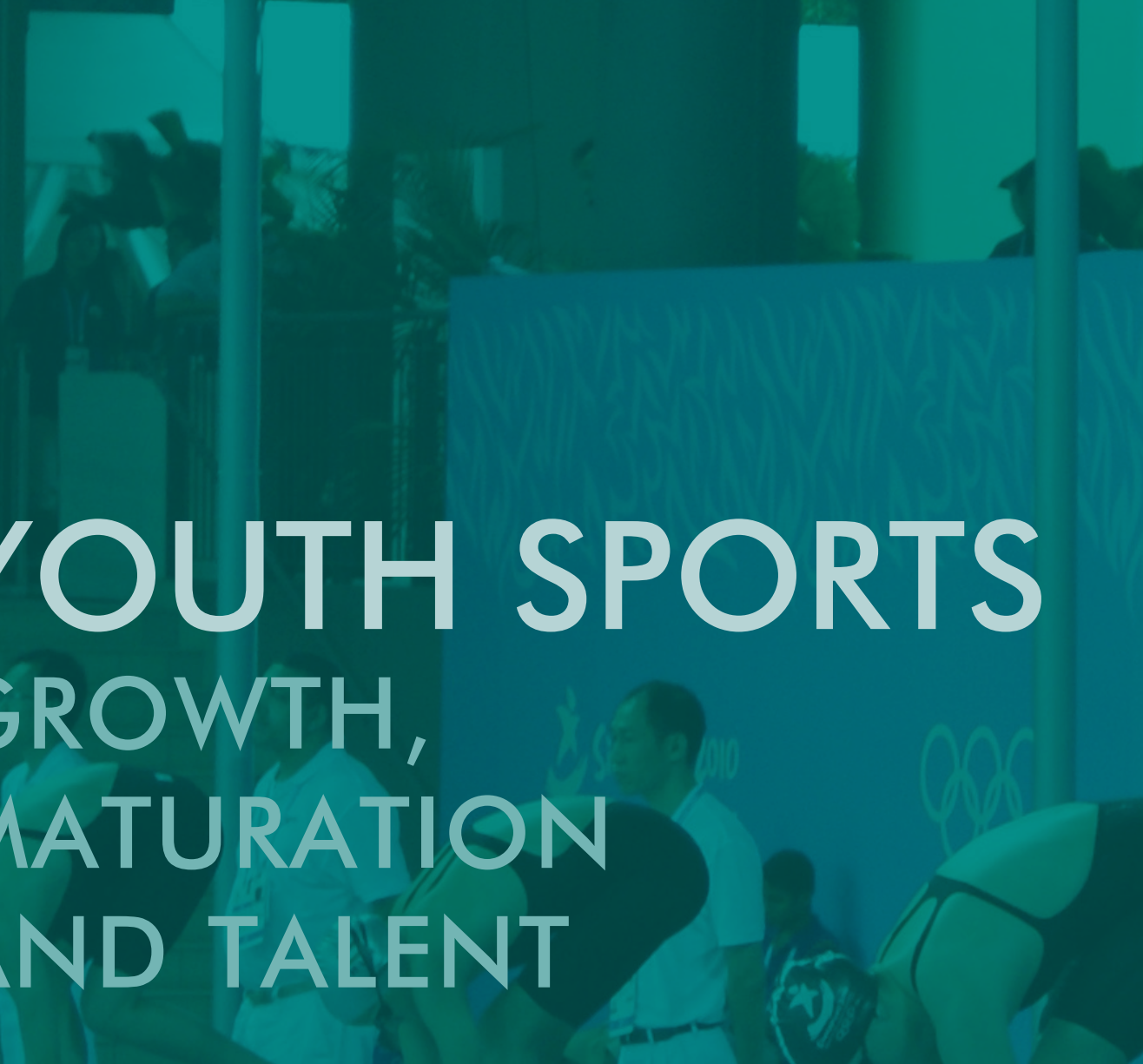

MANUEL J. COELHO E SILVA ANTÓNIO J. FIGUEIREDO MARIJE T. ELFERINK-GEMSER ROBERT M. MALINA

\section{EDITORS}

2. ' EDIÇÃO

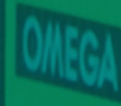

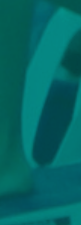




\section{CHAPTER 5: GROWTH AND MATURITY PROFILE OF YOUTH SWIMMERS IN MEXICO}

Maria E Peña Reyes

Robert M Malina

\section{INTRODUCTION}

Sport organization and participation in Mexico has developed considerably since the 1980s. Two factors are have apparently driven this expansion: (I) the assumption that most of the population should have access to sport in any of its different forms (youth sport, popular or recreational sport, and organized sport), and (2) strong interest in improving sport performances at national and international levels, i.e., high performance athletes (CONADE, I99|). In sports such as swimming or diving, opportunities for young participants are often limited due to scarcity of appropriate facilities throughout the country.

Studies of young athletes often focus on the "talented" and in many cases the elite (Malina, 1994, 1998). And, age-group swimmers are well represented among studies of the growth and maturity status of young athletes. Young swimmers are, on average, taller and heavier than reference data for the general population during childhood and adolescence, and in later elite adolescence swimmers tend to especially taller, but not exceptionally heavier. There is, needless to say, variation among studies and geographic regions (Malina, 1994, 1998). The data, however, are primarily available for Europe and the United States. Data for youth swimmers from Latin American countries are limited to reasonably select adolescent samples from Cuba (Alonso, 1986; Pancorbo and Rodriguez, 1986), Brazil (Rocha et al., 1977), and Venezuela (Perez, 1977, 198I), and a sample from the Bolivar Games in 1981 (Brief, 1986). More recently, the anthropometry and somatotype of an international sample of young adult swimmers, including those from Latin America, have been described (Carter and Ackland, 1994).

This paper is considers the growth and skeletal maturity status of youth swimmers from two urban centers in Mexico. They are participants in formal swim programs and are not, as a group, select, talented, or elite level swimmers. The data for this sample of Mexican youth swimmers are then compared to data for youth swimmers of approximately the same age from several Latin American countries. 


\section{METHODS}

The swimmers were part of larger study of the growth and maturity status of youth participants in several sports in different regions of the country in the late 1980s. The cross-sectional sample included 66 males 8.0 to 17.I years of age and 24 females 8.3 to 14.2 years of age. The swimmers were participants in youth swim programs two urban centers at central and northwestern Mexico. The programs and swimmers are not elite caliber. The children had been training in swimming for periods ranging from six months to two years. Younger children trained twice per week in hourly sessions, while older children trained three times per week in two hour sessions. This study thus provides data on the growth and maturity status of youth enrolled in less formal and less intensive swim programs.

Weight, height, sitting height, and the anthropometric dimensions needed to estimate Heath-Carter somatotype were taken: flexed arm and calf circumferences, bicondylar breadths of the humerus and femur, and the triceps, subscapular, suprailiac and medial calf skinfolds (Carter and Heath, 1990). The body mass index (BMI, $\left.\mathrm{kg} / \mathrm{m}^{2}\right)$ and sitting height/standing height ratio (\%) were also calculated.

Hand-wrist radiographs were taken to provide an estimate of skeletal maturity. The Fels method was used to estimate a skeletal age for each child (Roche et al., 1988); Fels assessments were not available for four boys and two girls. The radiographs were assessed by a single, experienced individual (MEPR; Peña Reyes, 1992; Peña Reyes and Malina, 200I).

Chronological age (CA) was subtracted from skeletal age (SA) for each child to provide an estimate of the skeletal maturity status of each swimmer as follows:

Late $($ delayed $)=$ SA behind CA by more than one year;

Average (on time) $=$ SA within plus or minus one year of CA;

Early (advanced) = SA ahead of CA by more than one year; and

Mature = skeletal maturity (an SA is not assigned).

The cut-off points are arbitrary and a broad range of average ("on time") is preferred to allow for error in the assessments (Malina et al., 2004).

The swimmers were divided into three chronological age groups for comparison. The age groups approximate, in general, those used in swimming competitions. Three groups were so designated in males: $8-10$ years $(n=20$,

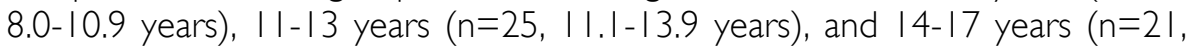


14.1-17.| years). Two groups were designated in females: $8-10$ years $(n=\mid 4$, 8.3- 10.9 years), and $\mid 1-14$ years $(n=|0| 1 \mid, .0-14.2$ years $)$.

Heights and weights of the swimmers were compared to growth charts for American children (Centers for Disease Control and Prevention, 2000). Satisfactory reference data for Mexican children are not available. The reference values commonly used are based on a mixed-longitudinal sample from a private clinical practice in the Federal District in the 1960s and 1970s (Ramos Galvan, 1975), which may not be representative of the Mexican population. The United States reference values are routinely used in growth and nutritional surveys worldwide.

\section{RESULTS}

Male Swimmers. Descriptive statistics for the three age groups of male swimmers are summarized in Table I. Mean heights approximate the $25^{\text {th }}$ percentile of United States reference data in the two younger age groups, but is between the $10^{\text {th }}$ and $25^{\text {th }}$ percentiles in the oldest age group. Mean weights, on the other hand, are just below the reference median in the 8-10 and 14-17 year age groups, but close to the $25^{\text {th }}$ percentile in the $11-13$ year age group. Swimmers in the two older age groups have, on average, proportionally longer legs than those in the youngest age group, which reflects growth in the lower extremities during the early part of adolescence (note, that the sample includes only few boys in late adolescence which is a period characterized by growth in length of the trunk).

Table I. Means (standard deviations) of male swimmers in three age groups.

\begin{tabular}{lcccccc}
\hline & \multicolumn{2}{c}{$\begin{array}{c}8-10 \text { yrs } \\
(\mathrm{n}=20)\end{array}$} & \multicolumn{2}{c}{$\begin{array}{c}\text { II-13 yrs } \\
(\mathrm{n}=25)\end{array}$} & \multicolumn{2}{c}{$\begin{array}{c}\text { I4-17 yrs } \\
(\mathrm{n}=21)\end{array}$} \\
\hline Age, yrs & 9.9 & $(0.8)$ & 12.3 & $(0.9)$ & 15.7 & $(0.9)$ \\
Height, $\mathrm{cm}$ & 134.9 & $(5.0)$ & 146.9 & $(9.7)$ & 164.6 & $(6.2)$ \\
Weight, $\mathrm{kg}$ & 30.3 & $(5.3)$ & 38.5 & $(9.1)$ & 58.0 & $(9.4)$ \\
BMI, $\mathrm{kg} / \mathrm{m}^{2}$ & 16.6 & $(1.9)$ & 17.7 & $(2.4)$ & 21.3 & $(2.3)$ \\
Sit Ht/Ht Ratio, \% & 52.5 & $(1.1)$ & 51.7 & $(1.4)$ & 51.7 & $(1.2)$ \\
Endomorphy & 2.4 & $(1.0)$ & 2.4 & $(1.1)$ & 2.5 & $(1.0)$ \\
Mesomorphy & 3.9 & $(1.1)$ & 3.8 & $(0.8)$ & 4.0 & $(0.8)$ \\
Ectomorphy & 2.8 & $(1.0)$ & 3.0 & $(1.1)$ & 2.3 & $(1.0)$ \\
\hline
\end{tabular}

Mean somatotypes of male swimmers show small differences between the two younger age groups, whereas swimmers in the oldest age group slightly more mesomorphic but are especially less ectomorphic (Table I). Mesomorphy is the dominant characteristic of swimmers in the three age groups. 
Skeletal maturity status of the male swimmers is summarized in Table 2. Mean skeletal age is within plus or minus one year of mean chronological age in the three age groups. Allowing for the relatively small sample sizes, the majority of swimmers in each of the three age groups is classified as average or "on time". Among 8-10 year old, late and early maturing swimmers are about equally represented. Among II-13 year old swimmers, 9 are classified as late and only one as early maturing, whereas among 14-17 year old swimmers, 4 are classified as early and 3 are already skeletally mature, and none is classified as late maturing. There thus appears to be a shift towards boys of average and advanced maturity status in the oldest age group of swimmers.

Table 2. Means (standard deviations) of male swimmers in three age groups in chronological age [CA], Fels skeletal age [SA], and frequencies of skeletal maturity classification.

\begin{tabular}{|c|c|c|c|c|c|c|c|c|c|c|}
\hline & \multicolumn{2}{|c|}{ CA, yrs } & \multicolumn{2}{|c|}{ SA, yrs } & \multicolumn{2}{|c|}{ SA - CA, yrs } & \multicolumn{4}{|c|}{ Maturity Classification* } \\
\hline $8-10$ yrs $(n=17)$ & 9.9 & $(0.9)$ & 10.3 & $(1.8)$ & 0.4 & $(1.8)$ & 5 & 9 & 3 & - \\
\hline $11-13$ yrs $(n=23)$ & 12.3 & $(0.9)$ & 11.7 & $(1.6)$ & -0.6 & $(1.1)$ & 9 & 13 & 1 & - \\
\hline $14-17$ yrs $(n=21)$ & 15.7 & $(0.9)$ & - & - & - & - & - & 14 & 4 & 3 \\
\hline Not mature $(n=18)$ & 15.6 & $(0.9)$ & 16.1 & $(1.3)$ & 0.5 & $(1.1)$ & & & & \\
\hline
\end{tabular}

Characteristics of $1 \mathrm{I}-13$ and $14-17$ year old swimmers of contrasting maturity status are summarized in Table 3. Late and average maturing $11-13$ year old, and average and early (including the skeletally mature) 14-17 year old swimmers are compared. Numbers in the youngest age group are too small for comparison. Within each age group, the more mature swimmers are taller and heavier, and have a larger BMI. The more mature 11-13 year old swimmers also have proportionally longer lower extremities (lower sitting height/standing height ratio), while the proportional difference is less 14-17 year old swimmers. Late and average maturing $11-13$ year old swimmers are, on average, similar in somatotype, whereas the more mature 14-17 year old swimmers are more mesomorphic and especially less ectomorphic.

Female Swimmers. Descriptive statistics for the two age groups of female swimmers are summarized in Table 4. Mean heights and weights of 810 year old swimmers fall just below the respective reference medians for American children. In contrast, mean height of swimmers $1 \mathrm{I}-14$ years approximates the $10^{\text {th }}$ percentile of the reference, while mean weight is at the $25^{\text {th }}$ percentile of the reference. Swimmers in the older age group have proportionally longer legs than those in the younger age group, which is expected since they are likely in adolescence. Mean somatotypes of female swimmers in the two age groups are virtually identical (Table 4). The 
somatotype is mesomorphic with balanced contributions of endomorphy and mesomorphy

Table 3. Means (standar deviations) of male swimmers $11-13$ and $14-17$ years grouped by maturity status.

\begin{tabular}{|c|c|c|c|c|c|c|c|c|}
\hline & \multicolumn{4}{|c|}{$11-13$ Years } & \multicolumn{4}{|c|}{ 14-17 Years } \\
\hline & \multicolumn{2}{|c|}{$\begin{array}{l}\text { Late } \\
(n=9)\end{array}$} & \multicolumn{2}{|c|}{$\begin{array}{c}\text { Average } \\
(n=13)\end{array}$} & \multicolumn{2}{|c|}{$\begin{array}{c}\text { Late } \\
(n=\mid 4)\end{array}$} & \multicolumn{2}{|c|}{$\begin{array}{c}\text { Average } \\
(n=7)\end{array}$} \\
\hline CA, yrs & 12.0 & $(0.8)$ & 12.6 & $(0.9)$ & 15.6 & $(1.0)$ & 15.8 & $(0.7)$ \\
\hline SA, yrs & 10.3 & $(0.9)$ & 12.6 & $(1.2)$ & 15.6 & $(1.1)$ & - & - \\
\hline SA - CA, yrs & -1.7 & $(0.7)$ & 0.0 & $(0.5)$ & 0.0 & $(0.5)$ & - & - \\
\hline Height, $\mathrm{cm}$ & 140.6 & $(4.6)$ & 151.6 & $(9.7)$ & 163.4 & $(6.2)$ & 167.1 & (5.7) \\
\hline Weight, kg & 33.8 & $(4.1)$ & 42.0 & $(9.9)$ & 55.9 & $(10.3)$ & 62.4 & $(5.6)$ \\
\hline BMI, kg/m2 & 17.1 & $(1.5)$ & 18.1 & $(2.8)$ & 20.8 & $(2.6)$ & 22.3 & $(1.3)$ \\
\hline Sit Ht/Ht Ratio, \% & 52.1 & $(1.4)$ & 51.5 & $(1.2)$ & 51.8 & $(1.2)$ & 51.5 & $(1.2)$ \\
\hline Endomorphy & 2.4 & $(1.0)$ & 2.4 & $(1.1)$ & 2.5 & $(1.1)$ & 2.3 & $(0.7)$ \\
\hline Mesomorphy & 4.0 & $(0.9)$ & 3.8 & $(0.9)$ & 3.9 & $(0.9)$ & 4.3 & $(0.6)$ \\
\hline Ectomorphy & 2.9 & $(0.8)$ & 3.0 & $(1.2)$ & 2.5 & $(1.1)$ & 1.9 & $(0.7)$ \\
\hline
\end{tabular}

*This group includes three swimmers who are already skeletally mature. They do not differ in age from the four swimmers who are adanced in skeletal age.

Table 4. Means (standard deviations) of female swimmers in two age groups.

\begin{tabular}{lcccc}
\hline & \multicolumn{3}{c}{$\begin{array}{c}8-10 \text { yrs } \\
(\mathrm{n}=14)\end{array}$} & \multicolumn{3}{c}{$\begin{array}{l}1 \mid-14 \text { yrs } \\
(\mathrm{n}=10)\end{array}$} \\
\hline Age, $\mathrm{yrs}$ & 9.5 & $(0.7)$ & 12.8 & $(1.0)$ \\
Height, $\mathrm{cm}$ & 133.8 & $(5.0)$ & 147.5 & $(5.4)$ \\
Weight, $\mathrm{kg}$ & 29.9 & $(6.0)$ & 39.2 & $(5.9)$ \\
$\mathrm{BMl}, \mathrm{kg} / \mathrm{m}^{2}$ & 16.7 & $(2.9)$ & 17.9 & $(1.8)$ \\
Sit Ht/Ht Ratio, \% & 53.0 & $(0.8)$ & 51.7 & $(1.1)$ \\
\hline Endomorphy & 2.7 & $(1.2)$ & 2.8 & $(0.7)$ \\
Mesomorphy & 3.7 & $(0.8)$ & 3.5 & $(0.8)$ \\
Ectomorphy & 2.9 & $(1.4)$ & 2.9 & $(0.9)$ \\
\hline
\end{tabular}

Table 5. Means (standard deviations) of female swimmers in two age groups in chronological age [CA], Fels skeletal age [SA], and frequencies of skeletal maturity classification

\begin{tabular}{|c|c|c|c|c|c|c|c|c|c|c|}
\hline & \multirow{2}{*}{\multicolumn{2}{|c|}{ CA, yrs }} & \multicolumn{2}{|c|}{ SA, yrs } & \multirow{2}{*}{\multicolumn{2}{|c|}{ SA - CA, yrs }} & \multicolumn{4}{|c|}{ Maturity Classification* } \\
\hline & & & & & & & $\mathrm{L}$ & A & $E$ & M \\
\hline $8-10$ yrs $(n=12)$ & 9.5 & $(0.7)$ & 9.9 & $(8.8)$ & 0.4 & $(0.7)$ & - & 11 & 1 & - \\
\hline $11-14$ yrs $(n=10)$ & 12.8 & $(1.0)$ & 12.7 & $(2.0)$ & -0.1 & $(1.8)$ & 4 & 4 & 2 & - \\
\hline
\end{tabular}

*Maturity Classification: L=late (delayed), A=average ("on time"), E=early (advanced), M=mature, see text for specific criteria.

Skeletal maturity status of the female swimmers is summarized in Table 5. Mean skeletal age is within plus or minus one year of mean chronological age in the two age groups. Allowing for the relatively small sample sizes, I5 of the total sample of 22 swimmers have skeletal ages that are classified as average or "on time". It is perhaps interesting that none of the 8-10 year old female 
swimmers are classified as late maturing. Among ||-|4 year old female swimmers, all three maturity categories are represented. Note, however, that sample sizes are small, and the suggested trends need to be interpreted with care. Given the small numbers, comparison of female swimmers | |-14 years of age of contrasting maturity status is not warranted.

\section{DISCUSSION}

In contrast to more elite samples of swimmers from United States and Europe, the present sample of swimmers is, on average, shorter and lighter. However, mean somatotypes are reasonably similar to those of other samples of age-group swimmers (Carter and Heath, 1990). Comparative data for body size and somatotype of youth swimmers of both sexes in several Latin American countries are summarized in Tables 6-7.

Table 6. Mean ages. heights. weights. and somatotypes of samples of Latin American youth male swimmers.

\begin{tabular}{|c|c|c|c|c|c|c|c|}
\hline & \multirow[b]{2}{*}{$\mathrm{n}$} & \multirow{2}{*}{$\begin{array}{l}\text { Age } \\
\text { (yrs) }\end{array}$} & \multirow{2}{*}{$\begin{array}{l}\text { Height } \\
(\mathrm{cm})\end{array}$} & \multirow{2}{*}{$\begin{array}{c}\text { Weight } \\
(\mathrm{kg})\end{array}$} & \multicolumn{3}{|c|}{ Somatotype* } \\
\hline & & & & & Endo & Meso & Ecto \\
\hline This study & 20 & 9.9 & 134.9 & 30.3 & 2.4 & 3.9 & 2.8 \\
\hline This study & 25 & 12.3 & 46.9 & 38.5 & 2.4 & 3.8 & 3.0 \\
\hline Cuba (a) & 14 & 12.5 & | 49.1 & 40.7 & 2.2 & 4.0 & 3.3 \\
\hline Venezuela (b) & 22 & 13.8 & I 58.2 & 46.5 & 1.8 & 4.3 & 3.7 \\
\hline This study & 21 & 15.7 & 164.6 & 58.0 & 2.4 & 4.0 & 2.3 \\
\hline Venezuela(b) & 17 & 17.2 & 175.6 & 68.0 & 2.2 & 4.9 & 3.0 \\
\hline
\end{tabular}

*Endo=endomorphy, Meso=mesomorphy, Ecto=ectomorphy; (a) Alonso, 1986; (b) Perez, 1977; (c) Perez, 198I; (d) Pancorbo and Rodriquez, 1986; (e) Brief, 1986

Table 7. Mean ages. heights. weights. and somatotypes of samples of Latin American youth swimmers.

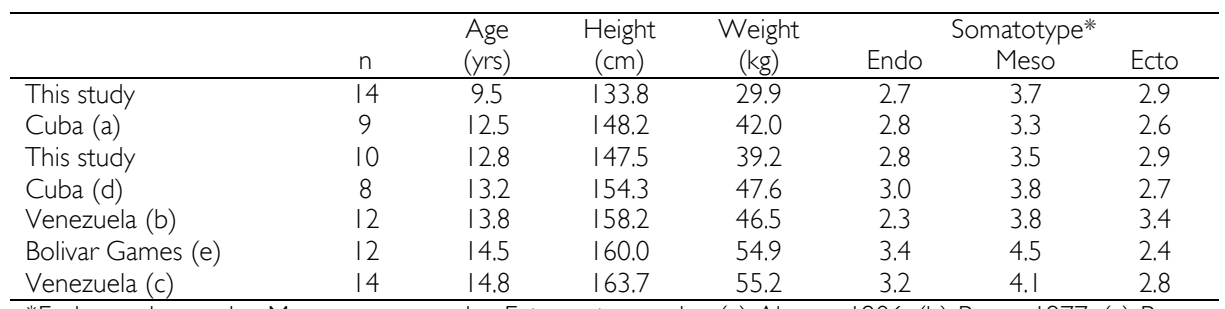

*Endo=endomorphy, Meso=mesomorphy, Ecto=ectomorphy; (a) Alonso, 1986; (b) Perez, 1977; (c) Perez, 1981; (d) Pancorbo and Rodriquez, 1986; (e) Brief, 1986

The present samples of male Mexican swimmers $8-10$ and $11-13$ years of age are, on average, similar in somatotype. The somatotype of male Mexican 
swimmers $11-13$ years (mean age 12.3 years) is similar to that Cuban swimmers of approximately the same mean age (12.5 years, Alonso, 1986), although the Mexican swimmers are slightly shorter and lighter. The older sample of male Mexican swimmers, 14 - 17 years (mean age 15.7 years), falls between the two Venezuelan samples of more elite status in body size, but is less mesomorphic and particularly less ectomorphic. The younger sample of Venezuelan swimmers is from a private club (Perez, 1977), while the older sample is nationally representative (Perez, 198I).

Female Mexican swimmers 8-10 and II-14 years of age are, on average, similar in somatotype. The sample of female Mexican swimmers II14 years (mean age 12.8 years) is intermediate in body size and somatotype to two samples of Cuban swimmers of approximately the same ages (Alonso, 1986; Pancorbo and Rodriguez, 1986). The older samples of female Latin American youth swimmers are especially more mesomorphic than the female Mexican swimmers. The sample of swimmers from the Bolivar Games of 1981 is most mesomorphic (Brief, 1986), followed by the nationally representative sample of Venezuelan swimmers (Perez, 1981).

Data for more elite samples of European and Australian male age group swimmers indicate skeletal ages (SA) which are concentrated in the average and advanced categories with relatively few late maturing youngsters in late childhood and early adolescence (Malina, 1994). This trend is also apparent in male swimmers at the XII Central American Swimming Championships in 198I (Peña Reyes et al., 1984). After 14-I5 years of age, elite male swimmers from the United States, Belgium, and the Central American Swimming Championships, and a small sample of Olympic swimmers under 18 years of age are advanced in skeletal maturity (Malina, 1994). The data for the present sample of non-elite Mexican males swimmers are generally consistent with these observations on more elite male swimmers, with the exception of the relatively large number of late maturing $(n=9)$ I I 13 year old swimmers.

The skeletal maturity data for the small sample of Mexican female swimmers is generally consistent with available data for more elite samples. In early adolescence, about 10-13 years, samples of elite female swimmers tend to have skeletal ages that are, on average, appropriate for their respective chronological ages, and most swimmers are classified in the average or "on time" category (Malina, 1994). On the other hand, skeletal ages of female participants 9-14 years of age in the XII Central American Swimming Championships in 1981 tended to be in advance of chronological age; at older adolecent ages, the elite swimmers tended toward late skeletal maturity status (Pena Reyes et al., 1984). 
The trends suggested for the skeletal maturity of youth swimmers need to be interpreted with care. The present study used the Fels method of skeletal maturity assessment (Roche et al., 1988). The earlier studies used either the Greulich-Pyle (GP) or Tanner-Whitehouse (TW) methods (Malina, 1994; see also Malina et al., 2004). Systematic comparisons of the methods of assessing skeletal maturity in samples of Mexican children are limited. In a sample of Mexican youth soccer players 7-17 years of age, SA-CA differences with the Fels and Tanner-Whitehouse II (TW II) methods were, on average, reasonably similar in players $<11,11-12$, and $>15$ years of age. However, among players 13-14 years of age, the SA-CA difference was, on average, more than twice as great with the TW II method than with the Fels method. Moreover, six boys were assessed as skeletally mature with the TW II method, while only one boy was assessed skeletally mature with the Fels method (Peña Reyes et al., 1994). Comparison of the Fels and TW II methods in a sample of marginally nourished children 6-13 years of age from an urban colonia (slum) in Oaxaca, southern Mexico, indicated that Fels skeletal ages lagged consistently behind chronological ages more so than TW II skeletal ages in both sexes. However, the heights of the children were more appropriate for Fels skeletal ages than for TW II skeletal ages (Peña Reyes and Malina, 200 I).

Although each method of assessing skeletal maturity yields a skeletal age, the skeletal ages are not directly comparable. The three methods of assessment are similar in principle, but differ in criteria for making assessments and procedures used to construct a scale of skeletal maturity from which skeletal ages are assigned. Detailed comparison of the three methods is beyond the scope of this paper. The reader is referred to a more detailed discussion of the three methods, including the most recent revision of the Tanner-Whitehouse method (TW III), in Malina et al. (2004). Nevertheless, systematic comparison of the Fels and Tanner-Whitehouse methods in samples of young athletes in different sports and in different countries is needed.

\section{REFERENCES}

Alonso RF (1986) Estudio del somatotipo de los atletas de 12 anos de la EIDE occidentales de Cuba. Boletin de Trabajos de Anthropologia, April, pp 3-18.

Brief FK (1986) Somatotipo y caracteristicas antropometricas de los atletas Bolivarianos. Caracas: Universidad Central de Venezuela.

Carter JEL, Ackland TR (1994) Kinanthropometry in Aquatic Sports: A Study of World Class Athletes. Champaign, IL: Human Kinetics.

Carter JEL, Heath BH (1990) Somatotyping: Development and Applications. Cambridge: Cambridge University Press.

Centers for Disease Control and Prevention (2000) National Center for Health Statistics (http://www.cdc.gov/growthcharts.htm), CDC growth charts: United States. 
CONADE (1991) Proyecto general de desarrollo de talentos deportivos. Mexico, D.F.: Comision Nacional del Deporte.

Malina RM (1994) Physical growth and biological maturation of young athletes. Exercise and Sport Sciences Reviews, 22, 89-433.

Malina RM (1998) Growth and maturation of young athletes: Is training for sport a factor. In KM Chang, L Micheli (Eds). Sports and Children. Hong Kong: Williams and Wilkins, pp |33-|6I.

Malina RM, Bouchard C, Bar-Or O (2004) Growth, Maturation, and Physical Activity, $2^{\text {nd }}$ edition. Champaign, IL: Human Kinetics.

Pancorbo AE, Rodriguez C (1986) Somatotype of high performance junior female swimmers. Boletin Cientifici-tecnico, Inder Cuba, I/2, 30-35.

Peña Reyes ME (1992) Aplication del metodo Fels para evaluar la maduracion del esqueleto en un grupo de niños de Oaxaca: Estudio comparativo de los métodos Fels y TW2. Mexico, D.F.: Instituto Nacional de Antropologia e Historia, Serie Antropologia Fisica.

Peña Reyes ME, Cardenas E, del Olmo JL (1984) Crecimiento y maduracion osea en deportistas preadolescentes y adolescentes. In R Ramos Galvan and RM Ramos Rodriguez (Eds). Estudios de Antropologia Biologica. II Coloquio de Antropologia Fisica Juan Comas, 1982. Mexico, D.F.: Instituto de Investigaciones Antropologicas, pp 453466.

Peña Reyes ME, Cardenas-Barahona E, Malina RM (1994) Growth, physique, and skeletal maturation of soccer players $7-17$ years of age. Humanbiologia Budapestinensis, 25, 453-458.

Peña Reyes ME, Malina RM (200I) Fels and Tanner-Whitehouse skeletal ages of school children 7-13 years in Oaxaca, Mexico. In P Dasgupta, R Hauspie (Eds). Perspectives in Human Growth, Development and Maturation. Dordecht, The Netherlands: Kluwer Academic Publishers, pp 55-65.

Perez BM (1977) Somatotypes of male and female Venezuelan swimmers. In $\bigcirc$ Eiben (Ed). Growth and Development; Physique. Budapest: Akademiai Kiado, pp 349-355.

Perez BM (198I) Los Atletas Venezolanos: Su Tipo Fisico. Caracas: Universidad Central de Venezuela.

Ramos Galvan R (1975) Somatometria Pediatrica. Estudio semilongitudinal de niños de la Ciudad de México. Archivos de Investigación Medica 6, Suppl I.

Rocha ML, Araujo CGS, de Freitas J, Villasboas LFP ( 1977) Antropometria dinamica da natacao. Revista de Educacao Fisica, Brasil, 102, 46-54.

Roche AF, Chumlea WC, Thissen D (1988) Assessing Skeletal Maturation of the HandWrist: Fels Method. Springfield, IL: CC Thomas. 
Página deixada propositadamente em branco. 